\title{
A Bibliometric Review of Research on Higher Education for Sustainable Development, 1998-2018
}

\author{
Philip Hallinger $1,2, * \mathbb{C}$ and Chatchai Chatpinyakoop ${ }^{1 /(])}$ \\ 1 College of Management, Mahidol University, Bangkok 10400, Thailand; chatchai.cht@mahidol.ac.th \\ 2 Department of Educational Leadership and Management, University of Johannesburg, Johannesburg 2006, \\ South Africa \\ * Correspondence: hallinger@gmail.com; Tel.: +66-81-881-1667
}

Received: 28 March 2019; Accepted: 18 April 2019; Published: 23 April 2019

\begin{abstract}
Over the last twenty years, higher education for sustainable development (HESD) has attracted increasing interest from scholars, students, and academic institutions globally. This bibliometric review of research analyzed 1459 Scopus-indexed documents related to higher education for sustainable development. The goals of the review were to document the volume, growth trajectory, and geographic distribution of the HESD literature, identify key authors, journals, and publications, analyze the intellectual structure of this knowledge base, and highlight emerging research issues. The review documented a rapidly growing knowledge base of recent vintage, mostly authored by scholars located in developed societies. Four core journals were identified, based on the volume of HESD publications and citation impact. Author co-citation analysis revealed three research clusters that underlie this knowledge base: Managing for Sustainability in Higher Education, HESD Competencies, and Implementation of HESD. This review provides a benchmark for future reviews of research on HESD, reveals the emerging intellectual structure of this inter-disciplinary field, and offers reference points for scholars entering this discipline.
\end{abstract}

Keywords: higher education; sustainability; sustainable development; bibliometric review; systematic review; university; education for sustainable development

\section{Introduction}

During the 1990s, concerns among educators over wasteful use of resources and the negative impact of economic development on the environment raised the profile of 'environmental education' [1]. This acted as the precursor of what came to be known as 'education for sustainable development' [1-3]. The past two decades have witnessed increased efforts by the international policy community to both raise awareness and integrate education into global policy initiatives aimed at sustainable development [1]. For example, the launch of the United Nations 'Decade of Education for Sustainable Development' in 2004 [2] aimed to integrate values, principles, and practices of sustainable development into formal and informal education. This was grounded in the belief that education paves the way for development of the knowledge and attitudes needed by citizens in every nation to create sustainable societies [3,4].

At the conclusion of the Decade of Education for Sustainable Development' in 2015, the United Nations adopted 17 sustainable development goals (SDGs), which reflected a broadening of the international effort to create sustainable societies. The SDGs codified the goal to ensure that all children have access to quality education that promotes life-long learning. Some scholars and policymakers have asserted that education for sustainable development is the most fundamental of the 17 SDGs. In a sense, education that is capable of fostering sustainable values, attitudes and behaviors among the next generation of global citizens is the key to achieving all of the SDGs. 
These perspectives on the aims and importance of education for sustainable development apply not only to primary and secondary education, but also to tertiary education. Indeed, tertiary education makes several unique contributions that differentiate its role in education for sustainable development from that of K-12 education. First, higher education institutions are responsible for preparing primary and secondary school teachers with the knowledge, skills, and attitudes needed to teach effectively for sustainability [5]. Second, the curricula taught across different disciplines in universities represent vehicles for preparing higher education students to incorporate sustainable attitudes and practices into their lives [6-10]. Finally, the role that universities play in knowledge creation has wide-ranging implications for global efforts to find 'sustainability solutions' [11,12]. These features suggest the suitability of analyzing HESD as a hybrid of the broader field of education for sustainable development [6,8-10].

Adomßent and colleagues defined higher education for sustainable development as the new educational cultures that "enable individuals to reflect through multicultural, global and future oriented perspectives, on their responsibility for the complex effects of decision-making and behavior" [13] (p. 2). This 'new learning is an open-minded, reflective, and participative process that examines the possibility of a sustainable future. Thus, scholars have referred to higher education for sustainable development not only as a 'subject' in the education curriculum, but also as a form of 'transformative learning' aimed at social change $[14,15]$.

Ávila and colleagues [16] recently analyzed literature related to 'sustainability' and 'education for sustainable development in K-12 and higher education settings'. They identified over 5000 documents published between 2005 and 2014 through a search of the Web of Science (WOS) as well as a special issue of the Journal of Cleaner Production. Like this review, Ávila and colleagues [16] used bibliometric methods to analyze the literature. The Ávila [16] review identified broad topical foci including health, education, management, energy, agriculture, and environmental issues. They reported that most of the publications in their review were authored in the USA, UK, China, Australia, and Canada. Analyses were also conducted aimed at identifying key journals, authors, and documents.

This bibliometric review of research is aimed extends these prior reviews of research by mapping the evolution of higher education for sustainable development from its inception in the late 1990s through 2018. Several research questions guided the review.

RQ 1. What is the overall volume, growth trajectory, and distribution of published documents across countries, type of papers, and research methods in the HESD knowledge base?

RQ 2. What journals, authors, and research papers have had the greatest influence on HESD research? RQ 3. What is the intellectual structure of the knowledge base underlying theory and HESD research? RQ4. What is the 'research front' or most frequently studied topics in recent years in the HESD literature?

This review identified a database consisting of 1459 Scopus-indexed documents comprised of journal articles, books, and books chapters. Bibliographic data associated with these documents were analyzed using Scopus analytical tools, Excel, Tableau, and VOSviewer software packages. Data analyses included descriptive statistics, direct citation analysis, co-citation analysis, social network analysis, and keyword co-occurrence analysis [17].

This review seeks to complement prior reviews of research that have examined the HESD knowledge base from the perspectives of implementation obstacles [18,19], teacher education [5,20], teaching and learning [14,21-23], and conceptual models [24,25]. Furthermore, as noted above, this review also seeks to extend findings reported by Ávila and colleagues [16] in their bibliometric review of HESD research.

\section{Materials and Methods}

This science mapping study of the literature used bibliometric methods to review research on higher education for sustainable development. Research reviews grounded in bibliometric methods do not examine the substantive findings of studies. Rather, their value extends from the capability 
to document and synthesize broad trends that describe the landscape, composition and intellectual structure of a knowledge base. Thus, science mapping offers insights into patterns of knowledge accumulation that would be difficult to 'see' using traditional methods of research review $[17,26]$.

\subsection{Identification of Sources}

Scopus was used as the index from which to identify documents for this review. Scopus offers a wide coverage of disciplines that were deemed relevant to HESD as well as access to bibliographic data used by bibliometric software [17]. While the Web of Science provides a similar capability for exporting meta-date for bibliometric analysis, its coverage of the education discipline is significantly less extensive than Scopus' [27].

Our search for relevant documents was framed by several criteria: Time, document type, topical focus, and language. At the outset, our goal of 'documenting the HESD knowledge base', it was decided not to set a specific time period for the publication of documents. Consequently, when conducting the search, the start date was left undefined; this allowed Scopus to identify all relevant documents published on HESD regardless of date. The review extended through 2018. This approach contrasts, for example, with Ávila and colleagues [16], who reviewed HESD research for a ten-year period from 2005 to 2014.

In terms of 'types of documents', the review included articles, book chapters, and books. Although Scopus does include a selection of conference papers, these were not included in the review. The rationale was that education conferences vary widely in the quality of review procedures and that conference presentations in education that generate useful knowledge often appear subsequently in journals. Moreover, the co-citation analyses used in this review enabled the authors to capture highly-cited conference papers via analysis of the reference lists of the review documents.

In terms of topical focus, a broad term, 'education for sustainable development in higher education', was chosen rather than a series of terms that presupposed particular definitions of the HESD construct (e.g., environmental education, peace education, inclusive education, health education). This approach assumed that authors writing on this topic 'self-organized' the literature through the use of terms used to describe their research in the title, abstract, and keywords of their papers.

The 'source' of documents was left open-ended during the search as opposed to predefining a specific set of journals. Although delimiting the search to a particular set of journals is another widely used search strategy $[27,28]$, the interdisciplinary nature of higher education for sustainability rendered this search strategy impractical. Finally, it was decided to limit the documents to those published in English since Scopus' coverage of documents in other languages remains quite uneven. This is, however, a limitation of the review that will be discussed subsequently.

The search process used in this review was informed by PRISMA guidelines for conducting systematic reviews of research [29]. The following keyword string was used to generate the initial database of documents in Scopus.

\section{TITLE-ABS-KEY (“higher education”) AND TITLE-ABSKEY}

\section{("sustainable development") OR TITLE-ABS-KEY ("sustainability")}

This search yielded 3057 documents. Scopus filters were used to screen out documents based on broad categories (e.g., document type, language, topical domains), which reduced the database to 2082 articles (see Figure 1). Next, the title and abstracts of documents were examined in order to determine eligibility based on 'topical relevance'. For example, numerous articles were eliminated that focused explicitly on ESD at the primary and secondary school levels, as well as articles whose primary focus was on 'sustainability' outside of education or on 'managing higher education institutions for sustainability'. This resulted in the exclusion of an additional 623 documents. This left a final database comprising 1459 articles for this review. 


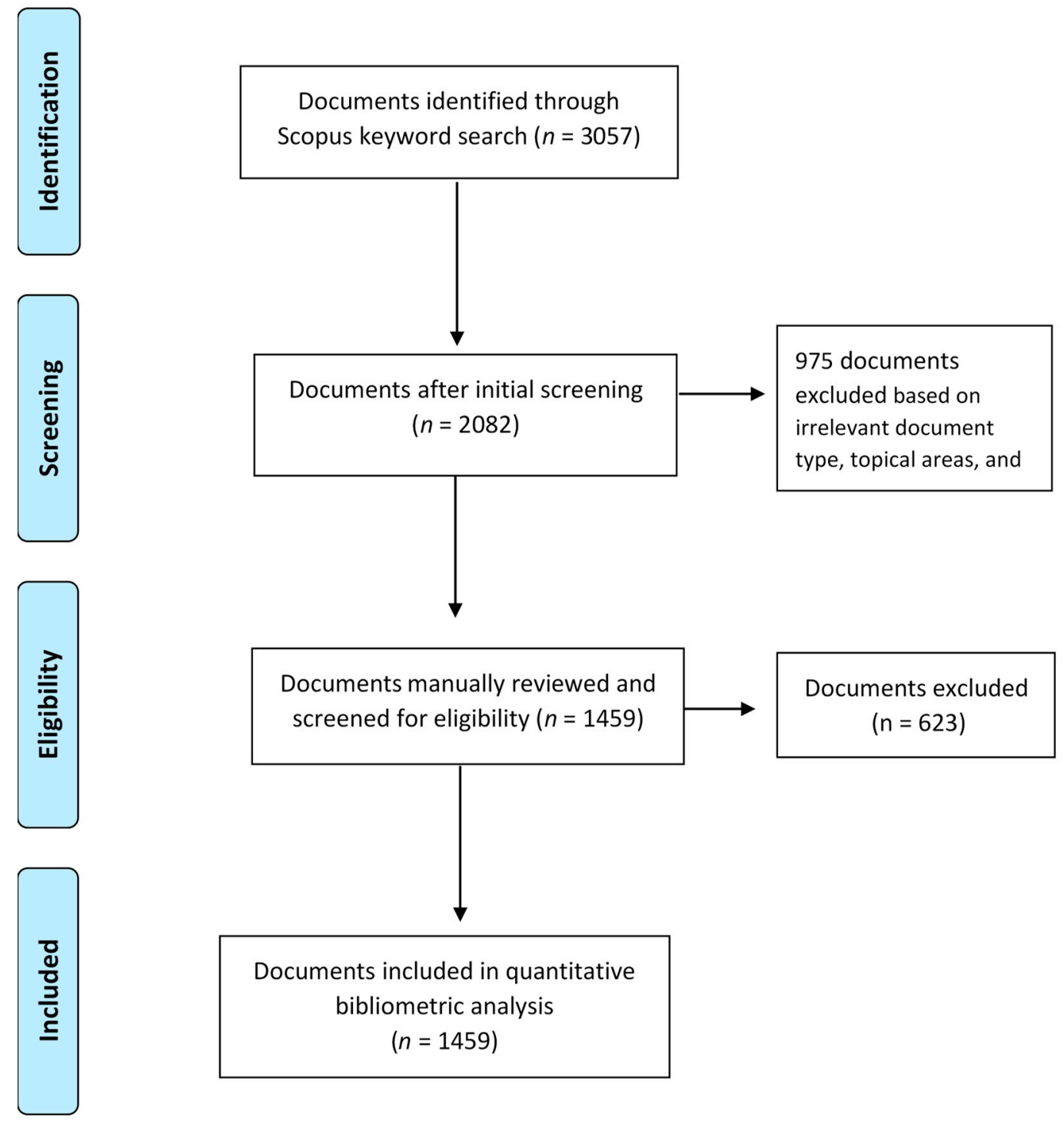

Figure 1. PRISMA diagram describing the collection of higher education for sustainable development (HESD) documents from the Scopus index [29].

\subsection{Data Extraction and Analysis}

We downloaded bibliographic data describing relevant features of the 1459 documents for storage in an Excel file. The file included 'meta data' related to each article, such as the author name(s), affiliations, article title, source, reference, keywords, abstracts, and various citation data.

We further prepared the data for analysis by creating a thesaurus file used to filter data during analysis in VOSViewer [30]. The thesaurus file is used to 'disambiguate' similar terms during data analysis. For example, the data file might include documents authored by the same scholar but with the name listed in different forms, such as 'Lang D.J.' and 'Lang D.'. The same problem could also occur with respect to similar keywords (e.g., "innovation" and "innovations") or document references. Use of a thesaurus file increases the accuracy of findings in bibliometric reviews [30].

Quantitative data analysis relied on a combination of descriptive statistics, citation analysis, co-citation analysis, and social network analysis. Descriptive statistics were used to document basic features of the knowledge base (e.g., size, growth trajectory, geographical distribution, paper type, research methods). Descriptive analyses were conducted using Scopus analytical tools, Tableau, and MS Excel software programs. 
Bibliometric analysis relies on 'direct citation' and 'co-citation' analyses, which serve distinct purposes [17]. Direct citation analysis was used to identify prominent authors, publications, and journals within the HESD knowledge base. Direct citation analysis calculates the number of times a document residing in the review database (i.e., the 1459 HESD documents) has been cited by other documents in the Scopus index. This review refers to citations calculated by direct citation analysis as 'Scopus citations'. If the review had been based on documents collected from the Web of Science or Google Scholar, the citation results would differ since these databases each contain a different number of documents. Citation analyses based on these indexes, therefore, yield a particular number of 'Web of Science citations' or 'Google Scholar citations'.

Co-citation analysis, a variant of citation analysis, offers complementary insights into scholarly influence. As defined by Zupic and Čater [17], co-citation is "the frequency with which two units [authors, documents, journals] are cited together" (p. 431). In co-citation analysis, the software package creates a matrix based on references cited in the 'reference lists' of documents contained in the review database (e.g., the 1459 documents). Co-citation analysis comes in several variants: Journal co-citation analysis, author co-citation analysis, document co-citation analysis. Each uses matrices of co-citation frequencies as the input for analysis.

Since co-citation analysis is based on documents listed in the reference lists rather than the review documents themselves, it captures a much larger and broader literature. This capability to include documents located outside the review database and outside of Scopus, enables co-citation analysis to provide a broader perspective on scholarly impact than is offered by direct citation analysis alone $[17,26]$. Thus, co-citation analysis complements the insights gained through direct citation analysis.

In addition to generating 'co-citation counts' (e.g., total co-citations), co-citation analysis also yields 'measures of similarity' between documents, authors, or journals $[17,26]$. More specifically, co-citation analysis can depict the relationship among authors in a field of study visually based on patterns of co-citation by other scholars. In this review, VOSviewer software was used to create visual representations or 'social network maps' of relationships among features of documents located in the HESD knowledge base [30]. Co-citation maps can be used to analyze various relational features of the knowledge base. For example, author co-citation maps can reveal the 'intellectual structure' of a knowledge base through analysis of similarities among the authors in the literature $[17,26,30,31]$.

For the final research question, keyword co-occurrence analysis or 'co-word analysis' was employed to highlight the topical composition of the HESD knowledge base [17,30]. Co-word analysis calculates the number of times two keywords occur together (i.e., co-occur) in the title, abstract, or keyword list of documents located in the review database [30]. Co-word analysis is able to identify keywords that frequently appear in the documents as well as show the relationship among these co-occurring keywords in a network map [17,30].

\section{Results}

The presentation of results is aligned to the four research questions.

\subsection{Volume, Growth Trajectory, and Distribution of the HESD Literature}

The 1459 HESD documents identified in the Scopus search comprised 1294 journal articles, 138 book chapters, and 27 books. This affirms that a substantial body of publications has emerged since publication of the first document on this topic in 1998 [32]. Longitudinal analysis of the database suggests that the HESD knowledge base has evolved in three broad stages (see Figure 2).

- Emergent growth stage from 1998 to 2004, during which 81 documents were published;

- Steady growth stage from 2005 to 2011, during which 380 documents were published;

- Accelerating growth stage from 2012 to 2018, during which 998 documents were published. 
These longitudinal data indicate that $64 \%$ of the HESCD literature has been produced during the past five years since 2013. These trends confirm that the HESD literature is of recent vintage and attracting rapidly increasing interest among scholars.

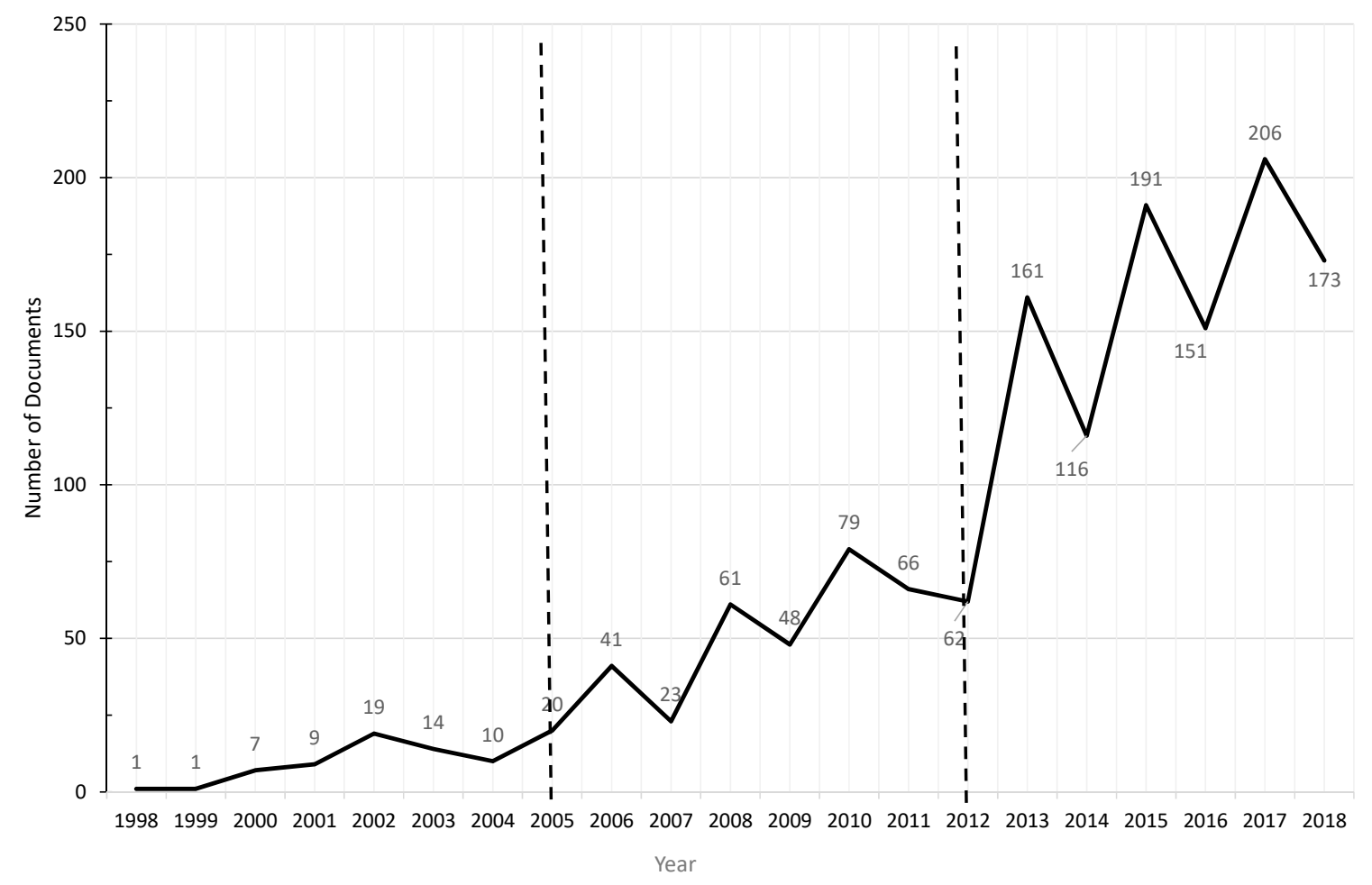

Figure 2. Growth trajectory of the higher education for sustainable development literature, 1998-2018 $(n=1459)$.

Although contributions to the HESD literature have come from scholars located in 100 different countries, there is a noticeable geographical imbalance in this knowledge base (see Figure 3). Most HESD studies have been authored by scholars located in relatively few societies. More specifically, scholars from the United States (USA), United Kingdom (UK), Canada, and Australia have produced $55 \%$ of the HESD literature. Scholars in several Northern European societies (e.g., Germany (68 documents), Spain (65), The Netherlands (60), Sweden (47)) have also been active contributors to this literature, accounting for an additional $13 \%$ of the HESD documents. Drilling down further, it was observed that $84 \%$ of the documents in the HESD database came from developed societies, and only $16 \%$ from developing societies. While this may be unremarkable in terms of comparison with publication trends in other disciplines, it is potentially problematic in a field such as HESD where implementation solutions may not always transfer readily.

Of the $16 \%$ of this literature that has been authored in developing societies, over $90 \%$ was published in the past eight years (not tabled). Further analysis of contributions from developing societies identified a number of 'emerging producers of HESD research': China (47), Malaysia (40), South Africa (40), Brazil (37), India (25), Mexico (18), and Turkey (15). While this suggests a positive trend, the numerous 'blank spots' on the heat map which almost entirely comprise developing societies cannot be ignored (see Figure 3). Indeed, societies in Africa and Latin America are highly conspicuous through their absence on the heat map. 


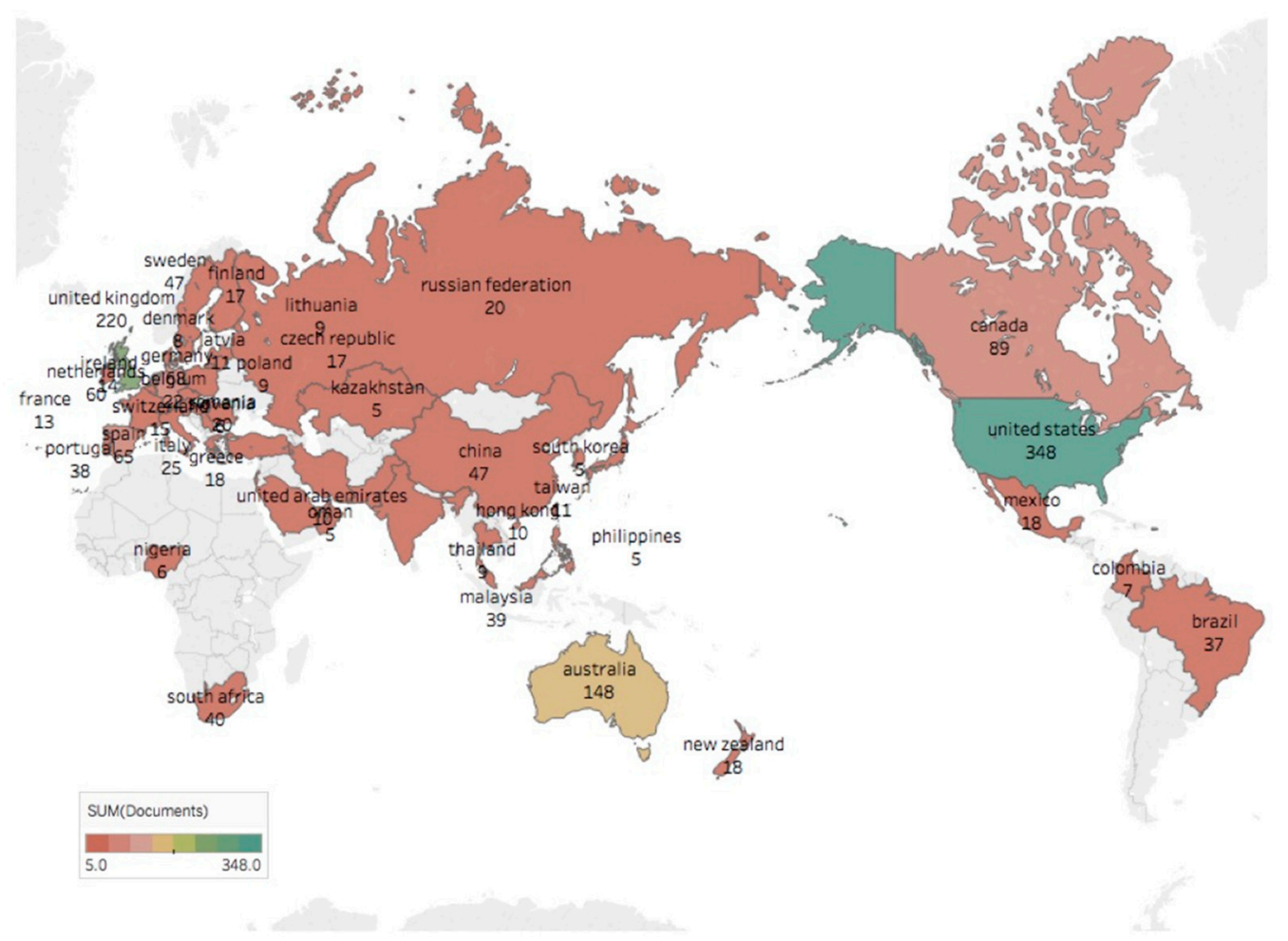

Figure 3. Geographical distribution of documents comprising the knowledge base in higher education for sustainable development, 1998-2018 $(n=1459)$.

\subsection{Influential Journals, Authors, and Documents}

The second research question sought first to understand how contributions to the HESD knowledge base were distributed across journals, and then to identify influential authors and documents.

The 1294 journal articles included in the review database were published in 152 different journals. On the positive side, this pattern of broad dispersion suggests that interest in HESD is not limited to a few 'specialty journals'. This was affirmed by analysis of the topical foci of journals publishing HESD research. Specifically, the range of journals publishing articles about HESD included journals specializing in education, higher education, education policy, educational administration, geography, science, the environment, engineering, energy, chemistry, construction, architecture, development, and energy (not tabled). The list of the top 20 journals ranked by total articles published highlights the cross-disciplinary spread of journals publishing HESD research (see Table 1).

Table 1. The 20 most active journals publishing HESD research ranked by number of articles indexed in Scopus, 1998-2018.

\begin{tabular}{clcccc}
\hline \multirow{2}{*}{ Rank } & \multicolumn{1}{c}{ Journal } & Count & $\begin{array}{c}\text { Scopus } \\
\text { Citations }\end{array}$ & $\begin{array}{c}\text { Subject } \\
\text { Scopus } \\
\text { Quartile }\end{array}$ \\
\hline 1 & International Journal of Sustainability in Higher Education & 268 & 5270 & ED, ENV & Q1 \\
2 & Journal of Cleaner Production & 129 & 3088 & ENV, ENG & Q1 \\
3 & Sustainability (Switzerland) & 81 & 371 & ENV, ENG \\
4 & Environmental Education Research & 35 & 332 & ENV, ENG, ED & Q1 \\
5 & Sustainability (United States) & 22 & 75 & ENV, ENG & Q3 \\
6 & International Journal of Sustainability Education & 21 & 15 & ED & Q4 \\
7 & Journal of Environmental Studies and Sciences & 18 & 55 & ED, DEV, SCI & Q2 \\
8 & Higher Education Policy & 15 & 343 & ED & Q2 \\
9 & Journal of Geography in Higher Education & 15 & 165 & ED, GEO & Q2 \\
10 & Environment Development and Sustainability & 12 & 84 & ENV, DEV \\
\hline
\end{tabular}


Table 1. Cont.

\begin{tabular}{|c|c|c|c|c|c|}
\hline Rank & Journal & Count & $\begin{array}{l}\text { Scopus } \\
\text { Citations }\end{array}$ & Subject & $\begin{array}{c}\text { Scopus } \\
\text { Quartile }\end{array}$ \\
\hline 11 & Higher Education & 11 & 122 & ED & Q1 \\
\hline 12 & Int'l Journal of Innovation and Sustainable Development & 11 & 81 & ENV, DEV & Q3 \\
\hline 13 & Journal of Teacher Education for Sustainability & 11 & 44 & ED & Q3 \\
\hline 14 & Australian Journal of Environmental Education & 10 & 81 & ENV, ED & Q2 \\
\hline 15 & Int'l Journal of Env Cult Econ. and Soc. Sustainability & 9 & 1 & ENV, DEV & Q4 \\
\hline 16 & Studies in Higher Education & 8 & 124 & ED & Q1 \\
\hline 17 & Green Energy and Technology & 8 & 0 & ENV, EN & Q3 \\
\hline 18 & Sustainability Science & 7 & 591 & ENV, SCI & $\widehat{\mathrm{Q}} 1$ \\
\hline 19 & Education and Training & 7 & 36 & $\mathrm{ED}$ & Q2 \\
\hline 20 & Journal of Security and Sustainability Issues & 7 & 24 & ENV, GEO & Q2 \\
\hline
\end{tabular}

We used VOSviewer software [28] to identify the most active (i.e., by volume) and influential (i.e. by Scopus citation counts) journals publishing HESD content (see Table 1). Using these dual criteria, the International Journal of Sustainability in Higher Education (IJSHE; Scopus 89\% and 100/979 among Education journals) and the Journal of Cleaner Production (JCP; Scopus 97\% and 9/316 among Industrial and Manufacturing Engineering journals) were identified as the top two HESD journals (see Table 1). The combination of strong citation impact and high ranking offer empirical verification of their positioning as the flagship journals in the HESD domain (see Table 1). These are followed by Sustainability (Switzerland) (S-S) and Environmental Educational Research (EER), which have also achieved prominence in this field of research (see Table 1).

Together, we suggest that these four journals can be considered 'core journals' in HESD. More broadly, the 20 journals listed in Table 1, which published $54 \%$ of all of the journal articles in the HESD database, were largely concentrated in Q1 and Q2 of the Scopus journal index. Scholars have critiqued the use of metrics such as impact factors, h-index, and cite scores for certain types of research evaluation. Nonetheless, these metrics are ubiquitous in higher education and offer a valid, though incomplete perspective on academic quality. In this study, the Scopus quartile was used to offer a broad perspective on journal quality in the field of HESD. The results suggest that much of the research in this field is meeting a good quality standard.

Next citation and co-citation analysis were used to identify the most active and influential scholars publishing on HESD topics (see Tables 2 and 3). The pattern of relatively low citation totals in Table 2 is a reflection of HESD's youthful vintage. Nonetheless, this citation analysis highlights the influential contributions of Riekmann (584 citations), Wiek (572), Huisingh (489), Barth (475), Wals (410), Ferrer-Balas (395), and R. Lozano (388). If scholarly productivity is also considered in terms of total contributions to this literature, Leal Filho and Shephard should also be added to this list of key authors.

Table 2. Most highly cited HESD authors ranked by Scopus citations, 1998-2018.

\begin{tabular}{|c|c|c|c|c|c|c|}
\hline Rank & Author & Country & Subject & Documents & $\begin{array}{l}\text { Scopus } \\
\text { Citations }\end{array}$ & $\begin{array}{l}\text { Citations } \\
\text { per } \\
\text { Document }\end{array}$ \\
\hline 1 & Rieckmann M. & Germany & ESD & 11 & 584 & 53.1 \\
\hline 2 & Wiek A. & USA & Env Edn & 6 & 572 & 95.3 \\
\hline 3 & Redman C. & USA & Env Edn & 2 & 506 & 253 \\
\hline 4 & Huisingh D. & USA & Env Edn & 10 & 489 & 48.9 \\
\hline 5 & Barth M. & Germany & ESD & 8 & 475 & 59.4 \\
\hline 6 & Wals A.E.J. & Netherlands & Env Edn, ESD & 6 & 410 & 68.3 \\
\hline 7 & Ferrer-Balas D. & Spain & HESD & 6 & 395 & 65.8 \\
\hline 8 & Lozano R. & Sweden & Env Edn, ESD & 10 & 388 & 38.8 \\
\hline 9 & Godemann J. & UK & Env Edn & 5 & 372 & 74.4 \\
\hline 10 & Withycombe L. & USA & ESD & 1 & 366 & 366 \\
\hline
\end{tabular}


Table 2. Cont.

\begin{tabular}{|c|c|c|c|c|c|c|}
\hline Rank & Author & Country & Subject & Documents & $\begin{array}{l}\text { Scopus } \\
\text { Citations }\end{array}$ & $\begin{array}{c}\text { Citations } \\
\text { per } \\
\text { Documen }\end{array}$ \\
\hline 11 & Munguia N. & Mexico & Env Edn & 2 & 337 & 168.5 \\
\hline 12 & Velazquez L. & Mexico & Env Edn & 2 & 337 & 168.5 \\
\hline 13 & Wright T.S.A. & Canada & Env Edn, ESD & 6 & 302 & 50.3 \\
\hline 14 & Leal Filho W. & Germany & Env Edn, ESD & 11 & 284 & 25.8 \\
\hline 15 & Shephard K. & New Zealand & ESD & 12 & 273 & 22.8 \\
\hline 16 & Svanström M. & Sweden & Env Edn, ESD & 4 & 268 & 67.0 \\
\hline 17 & Stoltenberg, U & Germany & ESD & 1 & 252 & 252 \\
\hline 18 & Ceulemans K. & France & HESD & 7 & 242 & 23.9 \\
\hline 19 & Thomas I. & Australia & Env Ed & 10 & 239 & 47.6 \\
\hline 20 & Moore J. & Canada & HESD & 5 & 238 & 23.4 \\
\hline
\end{tabular}

We complemented direct citation analysis of authors with author co-citation analysis. As indicated earlier, the value added by co-citation analysis lies in its ability to capture influential documents located outside of the review database, and indeed, outside of the Scopus index. Thus, scholars have asserted that co-citation analysis offers a broader perspective on scholarly influence than direct citation analysis $[17,26,31]$.

Table 3. Top 20 co-cited authors in the higher education for sustainable development literature, 1998-2018.

\begin{tabular}{clllcc}
\hline Rank & \multicolumn{1}{c}{ Author } & \multicolumn{1}{c}{ Nation } & \multicolumn{1}{c}{ Topical Focus } & Co-citations & $\begin{array}{c}\text { Total Link } \\
\text { Strength }\end{array}$ \\
\hline 1 & Lozano, R. & Sweden & ESD, Env Sustainability & 680 & 22,385 \\
2 & $*$ Sterling & UK & HESD, Learning & 432 & 10,558 \\
3 & Huisingh & USA & Env Sustainability & 410 & 15,004 \\
4 & $*$ Tilbury & Gibraltar & HESD, Curriculum & 379 & 9636 \\
5 & Wiek & USA & Env Sustainability & 375 & 11,998 \\
6 & Wals & Netherlands & ESD, Env Sustainability & 337 & 8689 \\
7 & Wright & Canada & HESD, Env Sustainability & 326 & 9317 \\
8 & Barth & Germany & ESD & 309 & 11,071 \\
9 & Rieckmann & Germany & ESD & 281 & 10,258 \\
10 & Thomas & Australia & Env Education & 274 & 8359 \\
11 & $*$ Lambrechts & Netherlands & HESD, Teaching \& Learning & 268 & 10,682 \\
12 & Leal Filho & Germany & ESD, Env Sustainability & 257 & 8040 \\
13 & Ferrer-Balas & Spain & HESD, Teaching \& Learning & 233 & 8340 \\
14 & Ceulemans & France & HESD, Teaching \& Learning & 209 & 8137 \\
15 & Godemann & UK & Env Sustainability & 196 & 6232 \\
16 & $*$ Lozano, F.J & Mexico & Env Sustainability & 193 & 7668 \\
17 & $*$ Lukman & Slovenia & ESD, Sustainable Development & 171 & 5987 \\
18 & Shephard & NZ & ESD & 166 & 3371 \\
19 & Redman & USA & Env Sustainability & 163 & 5301 \\
20 & $*$ Waas & Belgium & Env Sustainability & 155 & 6669 \\
\hline
\end{tabular}

ESD = education for sustainable development, HESD = higher education for sustainable development, Env = environmental.

* Indicates authors who were not listed among top 20 scholars by direct citations in Table 2.

The results of author co-citation analysis presented in Table 3 highlight several additional scholars who were not identified through direct citation analysis. Although this is not uncommon, the authors decided to check the direct citation counts of the asterisked scholars in Table 3. It was found that all of these highly co-cited scholars were, in fact, among the '50 most highly cited HESD scholars' as measured by direct citation. Thus, the results of the citation and co-citation analyses are largely overlapping and mutually reinforcing. Synthesis of the results of both types of author citation analysis yields a more comprehensive and valid list of influential authors. These include Lozano (R.), Sterling, Wiek, Wals, Barth, Rieckman, Huisingh, Tilbury, Ferrer-Balas, Leal-Filho, Wright, and Shephard. 
Other trends also accrue from these citation analyses. For example, half of the authors listed in the author co-citation table have focused on 'environmental sustainability' (e.g., Waas, Lukman, Redman). This highlights the 'broader reach' of co-citation analysis when compared with direct citation analysis. In addition, the geographical distribution of key authors reinforces the results of the earlier analysis, which found the HESD literature highly concentrated in a small number of economically developed societies. A perusal of Tables 2 and 3 finds only three scholars located in developing societies (F. Lozano, Munguia, and Velazquez, all from Mexico).

Next, a similar sequence of citation analyses was performed in order to identify the most influential documents in the HESD literature. Not surprisingly, many of the top-cited documents were authored by scholars featured in Tables 2 and 3 (e.g., Wiek, Barth, Brundiers, Rieckmann, Lozano, Velasquez, Shephard). The Scopus citation counts achieved by the top-cited HESD documents (see Table 4) fall in the moderate range when assessed against trends reported in other education literatures $[27,28]$. This further reinforces an image of HESD as an 'emerging literature'.

Table 4. Top cited documents on higher education for sustainable development by Scopus citations, 1998-2018 $(n=1459)$.

\begin{tabular}{|c|c|c|c|c|c|}
\hline Rank & Articles & $\begin{array}{l}\text { Paper } \\
\text { Type }\end{array}$ & Nation & $\begin{array}{l}\text { Scopus } \\
\text { Citations }\end{array}$ & $\begin{array}{l}\text { Cites } \\
\text { per year }\end{array}$ \\
\hline 1 & Wiek, A. et al. (2011). Key competencies in sustainability. [33] & Con & USA & 373 & 53.2 \\
\hline 2 & $\begin{array}{l}\text { Barth, M. et al. (2007). Developing key competencies for } \\
\text { sustainable development in higher education. [34] }\end{array}$ & Emp & AUS & 254 & 23.1 \\
\hline 3 & $\begin{array}{l}\text { Lozano, R. et al. (2013). Declarations for sustainability in } \\
\text { higher education. [35] }\end{array}$ & Emp & SWE & 241 & 48.2 \\
\hline 4 & $\begin{array}{l}\text { Velazquez, L. et al. (2006). Sustainable university: What can } \\
\text { be the matter? [20] }\end{array}$ & Emp & MEX & 176 & 14.7 \\
\hline 5 & $\begin{array}{l}\text { Sipos, Y. et al. (2008). Achieving transformative sustainability } \\
\text { learning. [15] }\end{array}$ & Emp & CAN & 175 & 17.5 \\
\hline 6 & $\begin{array}{l}\text { Leal Filho, W. (2000). Dealing with misconceptions on the } \\
\text { concept of sustainability. [36] }\end{array}$ & Con & GER & 174 & 9.7 \\
\hline 7 & $\begin{array}{l}\text { Shephard, K. (2008). Higher education for sustainability: } \\
\text { Seeking affective learning outcomes. [37] }\end{array}$ & Con & NZ & 166 & 16.6 \\
\hline 8 & $\begin{array}{l}\text { Velazquez, L. et al. (2005). Deterring sustainability in higher } \\
\text { education institution. [19] }\end{array}$ & Con & MEX & 164 & 12.6 \\
\hline 9 & $\begin{array}{l}\text { Wals, A. E., \& Jickling, B. (2002). "Sustainability" in higher } \\
\text { education. [38] }\end{array}$ & Con & NETH & 162 & 10.1 \\
\hline 10 & $\begin{array}{l}\text { Stephens, J. et al. (2008). Higher education as a change agent } \\
\text { for sustainability in different cultures... [10] }\end{array}$ & Con & USA & 158 & 15.8 \\
\hline 11 & $\begin{array}{l}\text { Kagawa, F. (2007). Dissonance in students' perceptions of } \\
\text { sustainable development and sustainability. [7] }\end{array}$ & Emp & UK & 155 & 14.1 \\
\hline 12 & $\begin{array}{l}\text { Lozano, R. (2010). Diffusion of sustainable development in } \\
\text { universities' curricula. [39] }\end{array}$ & Emp & SWE & 147 & 18.4 \\
\hline 13 & $\begin{array}{l}\text { Brundiers, K. et al. (2010). Real-world learning opportunities } \\
\text { in sustainability [40] }\end{array}$ & Con & USA & 146 & 18.3 \\
\hline 14 & $\begin{array}{l}\text { Steiner, G., \& Posch, A. (2006). Higher ed. for sustain-ability } \\
\text { by means of transdisciplinary case studies. [41] }\end{array}$ & Emp & $\mathrm{AT}$ & 125 & 10.4 \\
\hline 15 & $\begin{array}{l}\text { Thomas, I. (2004). Sustainability in tertiary curricula: What is } \\
\text { stopping it happening? [42] }\end{array}$ & Con & AUS & 124 & 8.9 \\
\hline 16 & $\begin{array}{l}\text { Ferrer-Balas et al. (2008). An international comparative } \\
\text { analysis of sustainability transformation. [43] }\end{array}$ & Emp & SPAIN & 121 & 12.1 \\
\hline 17 & $\begin{array}{l}\text { Wright, T. S. (2002). Definitions and frameworks for } \\
\text { environmental sustainability in higher education. [44] }\end{array}$ & Con & CAN & 118 & 7.4 \\
\hline 18 & $\begin{array}{l}\text { Shriberg, M. (2002). Institutional assessment tools for } \\
\text { sustainability in higher education. [45] }\end{array}$ & Con & USA & 114 & 7.1 \\
\hline 19 & $\begin{array}{l}\text { Lozano, R. (2015). A review of commitment and } \\
\text { implementation of sustainable development ... [18] }\end{array}$ & Emp & SWE & 112 & 37.3 \\
\hline 20 & $\begin{array}{l}\text { Svanström, M. et al. (2008). Learning outcomes for } \\
\text { sustainable development in higher education. [46] }\end{array}$ & Con & SWE & 108 & 10.8 \\
\hline 20 & $\begin{array}{l}\text { Rieckmann, M. (2012). Future-oriented higher education: } \\
\text { Which key competencies should be fostered ... ? [9] }\end{array}$ & Emp & GER & 108 & 17.7 \\
\hline
\end{tabular}


Topical themes encompassed among the top-cited documents (see Table 5) focused on defining the meaning and scope of HESD [36,44], identifying key competencies in HESD [9,33,34,37,46], managing for sustainability in higher education [45], exploring implementation challenges [10,18,19,31,38,42,43], and experimenting with new curriculum, teaching and learning approaches [7,15,39-41]. This suggests a concentration of interest in a relatively focused set of topical domains.

Table 5. Top co-cited documents on higher education for sustainable development, 1998-2018.

\begin{tabular}{|c|c|c|c|}
\hline Rank & Cited References & Type & Co-citations \\
\hline 1 & $\begin{array}{l}\text { Cortese, A. (2003). The critical role of higher education in creating a sustainable } \\
\text { future. [11] }\end{array}$ & Con & 55 \\
\hline 2 & $\begin{array}{l}{ }^{*} \text { Lozano, R. et al. (2013). Declarations for sustainability in higher education: } \\
\text { Becoming better leaders, through addressing the university system. [35] }\end{array}$ & Emp & 46 \\
\hline 3 & $\begin{array}{l}{ }^{*} \text { Barth, M. et al. (2007). Developing key competencies for sustainable } \\
\text { development in higher education. [34] }\end{array}$ & Emp & 40 \\
\hline 4 & $\begin{array}{l}\text { * Velazquez, L. et al. (2005). Deterring sustainability in higher education } \\
\text { institutions. [19] }\end{array}$ & Con & 33 \\
\hline 5 & $\begin{array}{l}\text { * Shephard, K. (2008). Higher education for sustainability: Seeking affective } \\
\text { learning outcomes. [37] }\end{array}$ & Con & 32 \\
\hline 6 & $\begin{array}{l}\text { * Wiek, A. et al. (2011). Key competencies in sustainability: A reference } \\
\text { framework for academic program development. [33] }\end{array}$ & Con & 30 \\
\hline 7 & $\begin{array}{l}\text { * Thomas, I. (2004). Sustainability in tertiary curricula: What is stopping it } \\
\text { happening? [42] }\end{array}$ & Con & 24 \\
\hline 8 & Warburton, K. (2003). Deep learning and education for sustainability. [47] & Con & 23 \\
\hline 9 & $\begin{array}{l}\text { Sharp, L. (2002). Green campuses: The road from little victories to systemic } \\
\text { transformation. [48] }\end{array}$ & Con & 22 \\
\hline 10 & $\begin{array}{l}{ }^{*} \text { Rieckmann, M. (2012). Future-oriented higher education: Which key } \\
\text { competencies should be fostered through university teaching and learning? [9] }\end{array}$ & Emp & 22 \\
\hline 11 & $\begin{array}{l}\text { Lozano, R. (2006). Incorporation and institutionalization of SD into universities: } \\
\text { Breaking through barriers to change. [49] }\end{array}$ & Con & 21 \\
\hline 12 & $\begin{array}{l}\text { Sipos, Y. (2008). Achieving transformative sustainability learning: Engaging } \\
\text { head, hands and heart. [15] }\end{array}$ & Con & 20 \\
\hline 13 & Lozano, R. (2011). The state of sustainability reporting in universities. [50] & Emp & 19 \\
\hline 14 & $\begin{array}{l}\text { Cotton, D. et al. (2009). Revolutions and second-best solutions: Education for } \\
\text { sustainable development in higher education. [51] }\end{array}$ & Emp & 18 \\
\hline 15 & $\begin{array}{l}\text { * Brundiers, K. et al. (2010). Real-world learning opportunities in sustainability: } \\
\text { from classroom into the real world. [40] }\end{array}$ & Con & 16 \\
\hline 16 & $\begin{array}{l}\text { Alshuwaikhat, H., \& Abubakar, I. (2008). An integrated approach to achieving } \\
\text { campus sustainability. [52] }\end{array}$ & Emp & 16 \\
\hline 17 & * Velazquez, L. (2006). Sustainable university: What can be the matter? [20] & Emp & 16 \\
\hline 18 & $\begin{array}{l}\text { Sterling, S., \& Thomas, I. (2006). Education for sustainability: The role of } \\
\text { capabilities in guiding university curricula. [53] }\end{array}$ & Con & 15 \\
\hline 19 & $\begin{array}{l}\text { Ferrer-Balas, D. (2010). Going beyond the rhetoric: System-wide changes in } \\
\text { universities for sustainable societies. [43] }\end{array}$ & Con & 15 \\
\hline 20 & Van Weenen, H. (2000). Towards a vision of a sustainable university. [54] & Con & 15 \\
\hline
\end{tabular}

${ }^{*}$ Indicates that this reference also appeared in Table 4 of top-cited documents. Emp = empirical; Con = conceptual/commentary; Rev $=$ review.

Next, document co-citation analysis was conducted in order to gain a broader picture of documents that have contributed to the development of this literature. It was interesting to note that the top 'co-cited document' authored by Cortese [11] did not feature in Table 4 of top-cited papers. Further investigation found that Cortese's [11] article was published in a journal, Planning in Higher Education, that is not indexed in Scopus. This illustrates the capacity of co-citation analysis to identify influential documents without limitation of the index used by the review.

Nonetheless, more broadly, there was a high degree of overlap between the highly-cited and highly co-cited documents displayed in Tables 4 and 5. Nine of the articles appeared on both lists: $[9,19,20,33-35,37,40,42]$. This further suggests the influence of these authors in the literature as well as the significance of the themes elaborated above in the discussion of the results in Table 4. It was again observed that the geographical distribution of authors in Tables 3 and 4 follows the pattern of Anglo-American-European authorship established in the earlier analyses. 
Any literature comprises a distribution of different types of research documents: Conceptual/commentary papers (i.e., conceptual analysis, critique, prescriptive), empirical studies, research reviews. A perusal of the 'types of papers' included among the influential HESD documents listed in Tables 4 and 5 found the following distribution: 19 conceptual/commentary papers, 13 empirical studies, and no reviews of research. Both the absence of research reviews and the relatively small proportion of empirical studies stood out as unusual when compared to other education literature [27,28]. Therefore, a follow-up analysis was conducted to determine if this particular pattern in Tables 4 and 5 extended to the full database.

Given the large number of documents in the HESD database, a sample of documents was coded and analyzed rather than the full set of papers. Two sampling formulas $[55,56]$ indicated that analysis of a random sample of 294 documents would yield a 95\% confidence interval. Thus, 294 documents were randomly selected and coded according to the three categories stated above. In contrast to the distribution noted among the highly-cited documents, the distribution for the full literature was: Conceptual/commentary $34 \%$, empirical $62 \%$, review $4 \%$. Based on the analysis of other education literatures $[27,28]$, this distribution suggests a reasonably balanced literature by types of research papers.

In the course of reviewing and coding the papers in the prior analysis, we became curious as to the analytical approaches being used in the empirical studies. Thus, these were coded as these as well using a three-category rubric of quantitative, qualitative, and mixed methods. The result indicated that the empirical literature on HESD consisted of 33\% quantitative, $49 \%$ qualitative, and $15 \%$ mixed methods studies. This was lower than expected with respect to quantitative papers. Moreover, when the statistical methods used in the quantitative studies were analyzed, there was a predominance of descriptive and simple correlational tests (not tabled).

\subsection{Intellectual Structure of the HESD Knowledge Base}

Next, author co-citation analysis was employed to reveal the intellectual structure of the knowledge base in HESD. This was accomplished in VOSviewer which generated an author co-citation map that visualizes similarities among the highly co-cited scholars in this literature. Out of a total of 46,314 authors in the author co-citation network (i.e., based on cited references in the reference lists of documents in the review database), 125 authors reached a threshold of at least 50 co-citations (see Figure 4).

McCain and White [26] proposed that authors who are frequently co-cited often share a commonality of perspectives or lines of inquiry with a field of study. Thus, on an author co-citation map, 'clusters' of co-cited authors are treated as proxies for common research traditions or 'Schools of Thought'. These clusters are indicated by a common color on the author co-citation map. The influence of an author within the literature is indicated both by the size of the node as well as the density of 'links' to other authors. Links between authors represent co-citations between those particular authors. The author co-citation map revealed three clusters or schools of thought comprising the HESD knowledge base.

The green cluster represents a school of thought focusing on managing for sustainability in higher education. Influential scholars in this school of thought include R. Lozano (680 co-citations), Huisingh (410), Wright (326), and Lambrechts (268). Examples of publications authored by scholars in this cluster include articles on sustainability assessment tools [45], sustainability reporting [50,57], and challenges to managing for sustainability in higher education $[18,19,35]$.

The blue cluster is a school of thought whose authors have sought to define and elaborate competencies in higher education for sustainable development. Key scholars include Wiek (375 co-citations), Barth (309), and Rieckmann (281). Publications within this school have examined the competencies required of university faculty to teach sustainability content (e.g., [34,58,59]) as well as priority competences for student attainment $[9,33,40,60]$. 


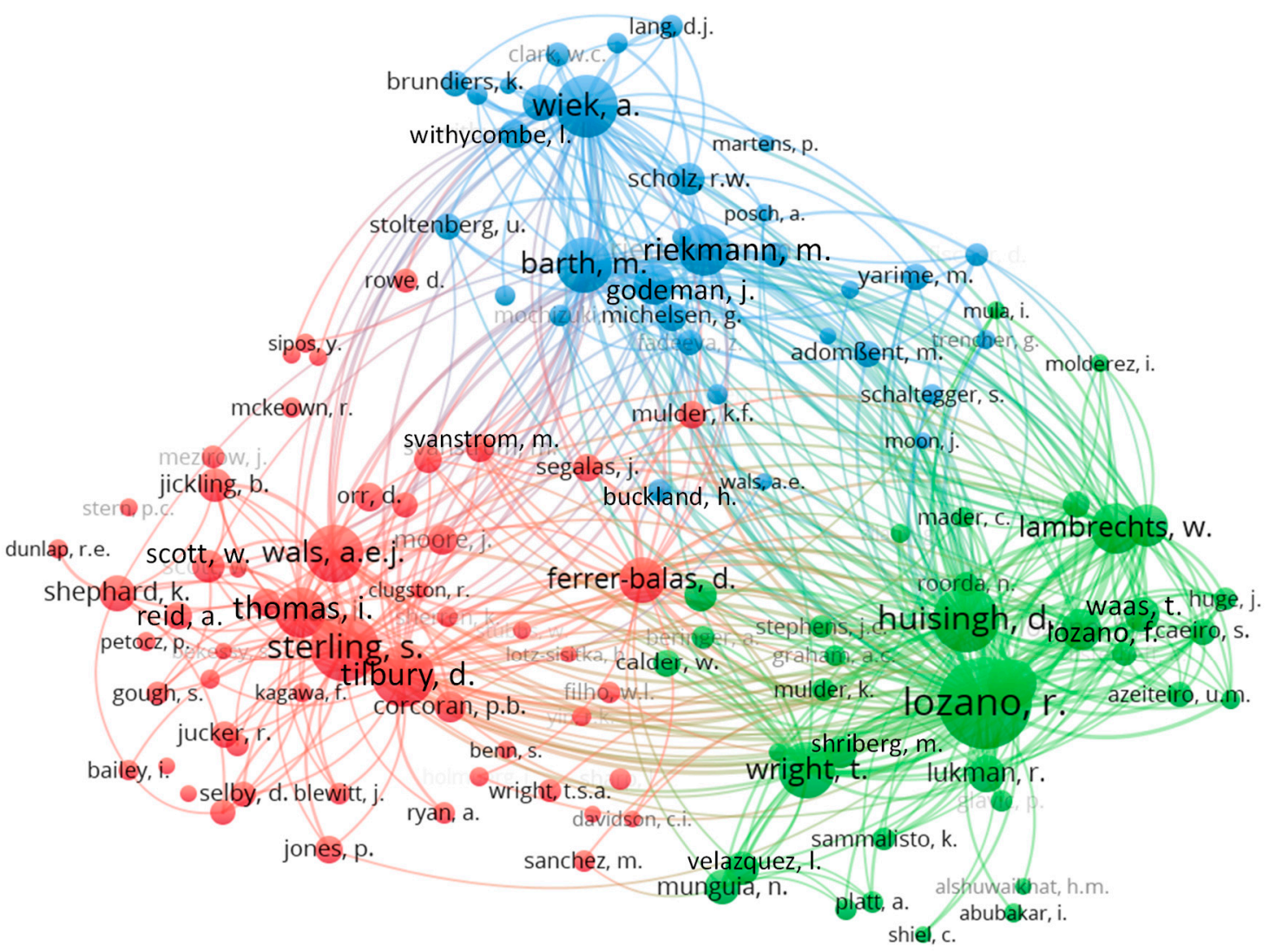

Figure 4. Author co-citation map of the literature on higher education for sustainable development, 1998-2018 ( $n=46,314$ authors in the co-citation network; threshold 50 citations per author, display 125 authors).

The red cluster represents a school of thought concerned with implementation of higher education for sustainable development. The most influential scholars within this school are Sterling (432 co-citations), Tilbury (379), Wals (337), Ferrer-Balas (233 co-citations), and Shepard (166). Issues addressed by scholars in this school include articulating the purposes of HESD [37,46], defining the scope of HESD [38,44,61,62], and addressing challenges associated with teaching and learning for sustainable development $[7,43,51,53,63,64]$.

\subsection{Topical Analysis of the HESD Literature}

The final research question concerned identification of the most frequently studied topics in recent HESD literature. Co-word analysis $[17,30]$ was used to identify the key topical foci in the HESD knowledge base. A key distinction between co-word analysis and the prior citation analyses is that co-word analysis examines the actual content (i.e., keywords) of documents as a means of synthesizing trends. Two kinds of co-word analysis were used to address this research question: frequency of keyword occurrence and temporal co-word analysis.

VOSviewer generates a temporal co-word map which can be used to reveal the frequency and recency of topics in this literature (see Figure 5). In the temporal co-word map, the size of the nodes reflects the frequency of keyword occurrence and colors reflect their relative recency. The software analyses the distribution of topic occurrence in documents over time and assigns lighter colors to topics whose distributions are concentrated in more recent years. Keywords and related themes identified through temporal co-word analysis represent the 'growing tip' [65] of the HESD literature. 


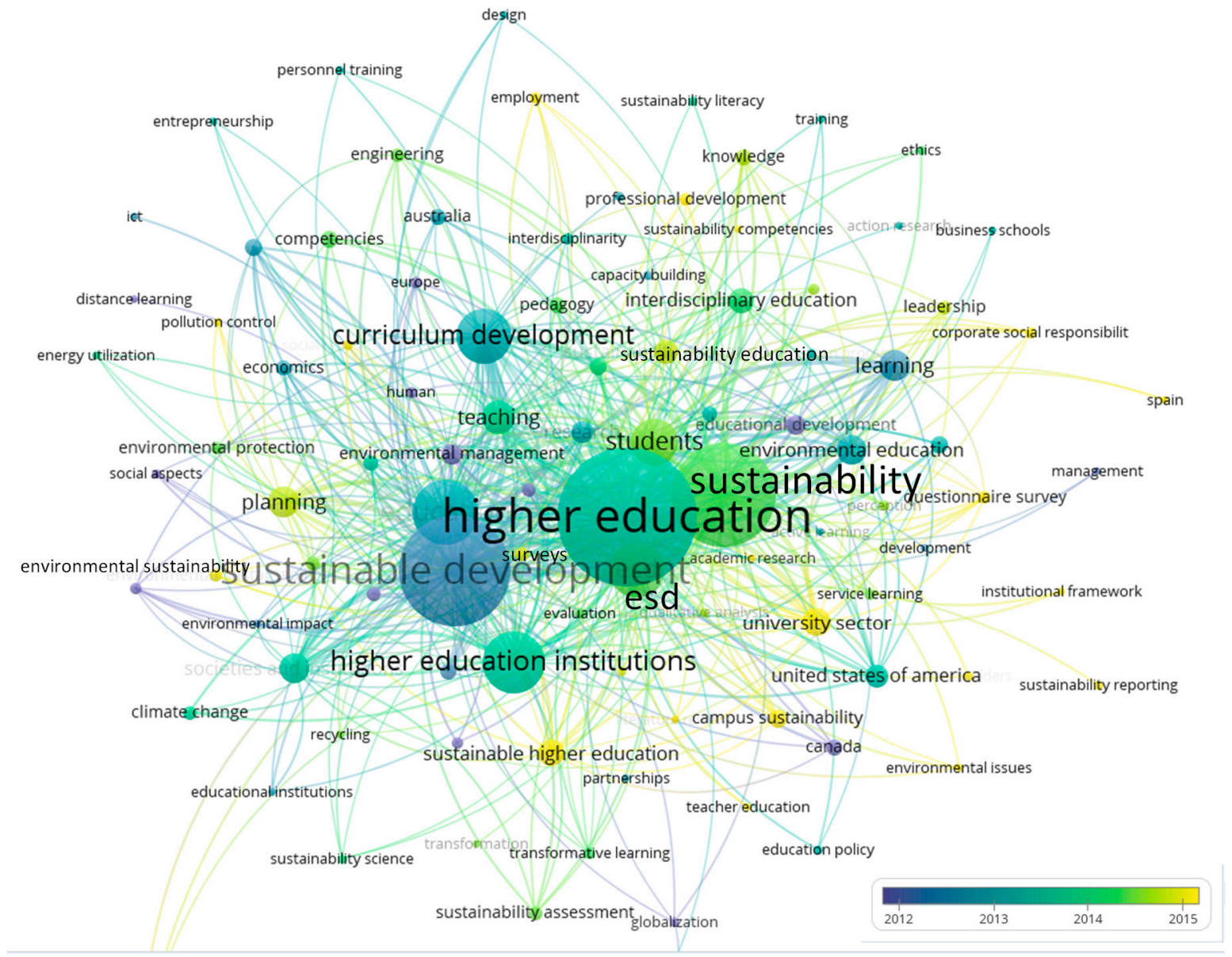

Figure 5. Temporal overlay on a co-word map of the literature on higher education for sustainable development, 2010-2016 (threshold 10 occurrences, display 100 keywords).

The first analysis examined the frequency of topics appearing in the HESD literature. After discounting the search terms (e.g., higher education, sustainable development, sustainability, education, education for sustainable development), the most frequent topics studied in this literature have been higher education institutions (204), curriculum development (172), students (137), teaching (81), learning (74), planning (73), environmental education (70), societies and institutions (70), university sector (66), interdisciplinary education (57), and sustainability education (51).

Our approach to identifying the 'research front' or topics of most recent interest involved synthesizing themes from related keywords in the HESD knowledge base [17,28,30]. First, topics with the lightest shade nodes were grouped into common themes, and then rank ordered based on frequency counts of the composite topics. Three main themes were identified in the HESD research front: Managing for Sustainability in Higher Education; Teaching, Learning, and Capacity Development in HESD; and Research and Development in HESD.

The first theme, Managing for Sustainability in Higher Education, focuses on sustainability of higher education institutions rather than 'higher education for sustainable development, per se. This theme encompasses two subsets of keywords. The first is concerned with the outcomes of sustainable higher education institutions (e.g., campus sustainability, environmental sustainability, corporate social responsibility). The second subset describes management processes that enable higher educational institutions to achieve these sustainability outcomes (e.g., leadership, institutional framework, sustainability reporting, sustainability assessment, stakeholders). 
The second theme, Teaching, Learning, and Capacity Development for HESD, focuses on core processes of education for sustainable development as it impacts teachers and learners. These core processes include the preparation and training of faculty (e.g., teacher education, professional development, sustainability competencies), innovative teaching-learning processes (e.g., teaching, problem-based learning, service learning, pedagogy, interdisciplinary education, innovation, transformative learning, educational technology), and a focus on learners (students, sustainability competencies).

The third theme refers to Research and Development in HESD. Related keywords reflecting this theme include research, questionnaires, research reviews, perception, and academic research. The more recent emphasis of these keywords in the HESD literature could be due to an increase in empirical research and research reviews during the latter period covered by this review.

\section{Discussion}

This systematic review of research sought to map the knowledge base on higher education for sustainable development through bibliometric analysis of 1459 Scopus-indexed documents published between 1998 and 2018. Science mapping focuses on illuminating trends in knowledge production rather than the synthesis of research findings. Thus, this review does not replace the need for reviews of research that examine the results of studies in this knowledge base. It was further noted that this review did not examine all documents relevant to higher education for sustainable development. While use of the Scopus index enabled the identification of a large body of documents, it is not possible to determine the extent to which these findings are representative of the entire literature. It was, for example, noted that the scope of this review was delimited by the types of sources and the index from which documents were extracted. The impact of this limitation was, however, reduced somewhat by the use of co-citation analysis, which enabled the identification of the 'co-cited' documents located in the broader literature omitted from Scopus.

This was the first bibliometric review that has focused 'explicitly on the HESD literature'. Thus, the identification of 1459 Scopus-indexed topics published since 1998 offers a baseline against the future growth of this field. Longitudinal analysis of this database documented rapidly accelerating growth in HESD publications over the past decade. This trend was consistent with findings reported by Ávila and colleagues [16], though their review, was not limited to HESD and focused on a shorter period of time (i.e., 2005 to 2014). Nonetheless, based on the similar trend documented in both reviews, it is likely that the HESD knowledge base will more than double in size by 2025 .

Analysis of the composition of the knowledge base by 'type of paper' found a reasonable distribution among empirical, conceptual/commentary, and review papers. However, the proportion of quantitative papers was lower than expected, as was the proportion of quantitative studies using advanced statistical analysis. Although the authors have no bias towards a particular type of research methodology, it is suggested that a 'mature knowledge base' $[27,28]$ would need to incorporate analytical methods capable of discerning the effectiveness of different approaches to HESD. Based upon this bibliometric analysis, the current emphasis on empirical research that employs qualitative and simple quantitative methods is a limitation of the current knowledge base. This finding should be examined in a future review that examines the literature from this particular perspective.

Another notable feature of the HESD knowledge base identified in this review is its concentration in a small set of economically developed, Western societies. More specifically, it was found that only $16 \%$ of the literature was authored in developing societies. This is problematic for several reasons. First, it cannot be assumed that sustainability perspectives and solutions are readily transferable $[27,66]$. Moreover, the greater the cultural and socioeconomic gaps between policy sources and implementation targets, the greater the challenges for successful implementation [67]. This suggests the need for HESD research that is grounded in a broader set of cultural, institutional, and socioeconomic contexts [27]. Second, scholars predict that the effects of 'unsustainable development' will be felt most severely in developing societies [68]. Resource scarcity in developing societies frequently leads to a survivalist 
mindset that leads policymakers to borrow against the future. In addition, when the effects of unsustainable development do arise in developing societies, fewer resources are available to buffer the impact.

Our journal analysis concluded that the HESD literature is being published in a widely dispersed, cross-disciplinary group of good quality journals. These journals specialize in education, engineering, science, management, economic and social development, policy, and the environment. The results of the journal analysis were broadly consistent with those reported by Ávila and colleagues [16]. More specifically, it was found the most frequent venues for HESD scholarship were International Journal of Sustainability in Higher Education (ranked 3rd by Ávila and colleagues) Journal of Cleaner Production (ranked 1st by Ávila and colleagues), Sustainability (Switzerland) (ranked 4th by Ávila and colleagues), and Environmental Education Research (ranked 2nd by Ávila and colleagues). The consistency in results between the two reviews is more significant than the small differences in rank ordering of the journals. Moreover, these can be attributed to differences in the length and foci of the different reviews. In contrast to Ávila and colleagues [16], this review extended the analysis of HESD journal publications to include the analysis of scholarly impact. Using direct citation analysis, it was found that the rank of journals by citation impact mirrored the rank order by volume (see Table 1). Thus, IJSHE, JCP, S-S and EER represent the 'core journals' publishing research on HESD. Furthermore, as noted earlier, these are all high-quality journals, especially IJSHE, JCP, and EER, each of which is highly ranked among Scopus journals in their subject domains.

White and McCain [26] asserted that a strength of bibliometric analysis is its capacity to identify key authors and texts through empirical analysis of the literature. This review's citation and co-citation analyses documented scholars who have, to date, made signal contributions to the development of this literature. These include Lozano (R.), Sterling, Wiek, Wals, Barth, Rieckman, Huisingh, Tilbury, Ferrer-Balas, Leal-Filho, Wright, Godeman, Ceulemans, and Shephard.

Similarly, key documents were identified that have shaped the evolving discourse in HESD (e.g., $[10,11,19,20,33,34,37,40,42,58]$ ). Although the findings with respect to key authors showed considerable overlap with those reported by Ávila and colleagues [16], the results concerning highly-cited documents diverged sharply. More specifically, in the Ávila [16] review documents focusing on 'sustainability science' dominated the list of highly-cited documents. This reflects the emergence of sustainability science as an outgrowth of research on sustainable development in the last decade [16]. However, sustainability science was not explicitly included in the search terms used in this review, and therefore did not feature in the highly cited documents. Thus, readers are encouraged to interpret the results of this review of HESD in concert with the results of reviews that adopted different databases, perspectives, and methods $[3-6,13,16]$.

Our final analyses sought to identify the intellectual structure and the research front of the HESD literature. Author co-citation analysis yielded three main schools of thought comprising the intellectual structure of the HESD knowledge base: Managing for Sustainability in Higher Education, Competencies in Higher Education for Sustainable Development, and Implementation of Higher Education for Sustainable Development. This identification of the thematic structure of the HESD knowledge base points scholars towards key lines of inquiry that deserve attention in the future.

Finally, co-word analysis was used explore the 'research front' [65] in HESD scholarship. The analysis of frequently co-occurring keywords yielded a complementary set of themes which suggest the most current topics of interest among HESD scholars. These included Managing for Sustainability in Higher Education; Teaching, Learning, and Capacity Development in HESD; and Research and Development in HESD. These findings on 'hot topics' again diverged from those reported by Ávila and colleagues [16], who employed a contrasting methodology to an overlapping but distinctly different dataset.

Our findings suggest several implications. First, although this review's focus on English language publications could have distorted this picture, the findings suggested that the capacity for conducting research on HESD is poorly distributed across the globe, with relatively little research from developing 
societies (see Figure 4). Indeed, this result is consistent with findings reported in a recent bibliometric research of research in education administration, which identified a trend of limited but increasing research production outside of Anglo-American-European societies [27]. Nonetheless, increasing the density of HESD beyond traditional centers of academic research should represent an urgent priority. More specifically, it implies a need for formal programs of research funding designed to stimulate HESD research in developing societies. Fortunately, there was also a pattern of growth over the past decade in HESD research authored by scholars in developing societies (e.g., China, Brazil, Malaysia, Mexico, South Africa). Thus, one could expect a positive response to international efforts aimed at further stimulating interest, developing capacity, and supporting empirical studies among HESD scholars in developing societies.

Second, the delimitation of this review to 'higher education for sustainable development' yielded findings that complement and extend those previously reported in this literature [16]. The findings were an empirically-verified list of key journals, documents, and authors that have shaped the discourse in this domain. These analyses have practical utility for scholars working within this literature. For example, the key scholars and documents identified in this review offer 'entry points' for new HESD scholars, reducing the time needed to get up to speed on key conceptual themes and empirical findings. The identification of the emerging intellectual structure of HESC scholarship highlights some key domains that may be ripe for further review using traditional narrative, thematic, and critical synthesis review methods.

Third, the findings with respect to the research methods that predominate in the HESD knowledge base represent a limitation and a potential cause for concern. Qualitative research and prescriptive reports are capable of offering useful descriptive insights into a variety of important issues. However, these findings suggest a need to incorporate more sophisticated research designs capable of documenting and contextualizing educational practices in a rapidly changing, cross-disciplinary field of research and practice. Sustainability scholars should consider tools being used in future research $[69,70]$ as well as complexity science [71,72]. These seem well suited to the challenges of studying education for sustainability.

Finally, stepping back from specific findings, this review reinforces the growing recognition that education will play a key role in the global effort to achieve the UN's sustainable development goals. This is evident in the growth trajectory of the HESD literature, its cross-disciplinary composition, the breadth of journals featuring HESD content, and the quality of journals and scholars that have engaged with this topic. Together, these trends cohere into a picture of an emerging interdisciplinary field of scholarship with the potential to impact policy and practice in the years to come.

Author Contributions: The authors collaborated on all parts of the research including framing of the study, collection and analysis of documents, and writing of the results.

Funding: This research received funding support from the Thailand Sustainable Development Foundation.

Conflicts of Interest: The authors declare no conflict of interest.

\section{References}

1. Jickling, B.; Wals, A.E. Debating education for sustainable development 20 years after Rio: A conversation between Bob Jickling and Arjen Wals. J. Educ. Sustain. Dev. 2012, 6, 49-57. [CrossRef]

2. UNESCO. United Nations Decade of Education for Sustainable Development (2005-2014). International Implementation Scheme. 2005. Available online: http://unesdoc.unesco.org/images/0014/001486/148654e.pdf (accessed on 12 November 2018).

3. Aikens, K.; McKenzie, M.; Vaughter, P. Environmental and sustainability education policy research: A systematic review of methodological and thematic trends. Environ. Educ. Res. 2016, 22, 333-359. [CrossRef]

4. Salas-Zapata, W.A.; Ríos-Osorio, L.A.; Cardona-Arias, J.A. Knowledge, attitudes and practices of sustainability: Systematic review 1990-2016. J. Teach. Educ. Sustain. 2018, 20, 46-63. [CrossRef] 
5. Chinedu, C.C.; Wan-Mohamed, W.A.; Ogbonnia, A.A. A systematic review on education for sustainable development: Enhancing TVE teacher training programme. J. Tech. Educ. Train. 2018, 10, 109-125.

6. Figueiró, P.S.; Raufflet, E. Sustainability in higher education: A systematic review with focus on management education. J. Clean. Prod. 2015, 106, 22-33. [CrossRef]

7. Kagawa, F. Dissonance in students' perceptions of sustainable development and sustainability: Implications for curriculum change. Int. J. Sustain. High. Educ. 2007, 8, 317-338. [CrossRef]

8. Lozano, R.; Lozano, F.J.; Mulder, K.; Huisingh, D.; Waas, T. Advancing higher education for sustainable development: International insights and critical reflections. J. Clean. Prod. 2013, 48, 3-9. [CrossRef]

9. Rieckmann, M. Future-oriented higher education: Which key competencies should be fostered through university teaching and learning? Futures 2012, 44, 127-135. [CrossRef]

10. Stephens, J.C.; Hernandez, M.E.; Román, M.; Graham, A.C.; Scholz, R.W. Higher education as a change agent for sustainability in different cultures and contexts. Int. J. Sustain. High. Educ. 2008, 9, 317-338. [CrossRef]

11. Cortese, A.D. The critical role of higher education in creating a sustainable future. Plan. High. Educ. 2003, 31, 15-22.

12. Martens, P. Sustainability: Science or fiction? Sustain. Sci. Pract. Policy 2006, 2, 36-41. [CrossRef]

13. Adomßent, M.; Fischer, D.; Godemann, J.; Herzig, C.; Otte, I.; Rieckmann, M.; Timm, J. Emerging areas in research on higher education for sustainable development-management education, sustainable consumption and perspectives from Central and Eastern Europe. J. Clean. Prod. 2014, 62, 1-7. [CrossRef]

14. Boström, M.; Andersson, E.; Berg, M.; Gustafsson, K.; Gustavsson, E.; Hysing, E.; Lidskog, R.; Löfmarck, E.; Ojala, M.; Olsson, J.; et al. Conditions for transformative learning for sustainable development: A theoretical review and approach. Sustainability 2018, 10, 4479. [CrossRef]

15. Sipos, Y.; Battisti, B.; Grimm, K. Achieving transformative sustainability learning: Engaging head, hands and heart. Int. J. Sustain. High. Educ. 2008, 9, 68-86. [CrossRef]

16. Ávila, L.V.; Rossato Facco, A.L.; Bento, M.H.D.S.; Arigony, M.M.; Obregon, S.L.; Trevisan, M. Sustainability and education for sustainability: An analysis of publications from the last decade. Environ. Qual. Manag. 2018, 27, 107-118.

17. Zupic, I.; Čater, T. Bibliometric methods in management and organization. Organ. Res. Methods. 2015, 18, 429-472. [CrossRef]

18. Lozano, R.; Ceulemans, K.; Alonso-Almeida, M.; Huisingh, D.; Lozano, F.J.; Waas, T.; Lambrechtshi, W.; Lukmanjk, R.; Hugé, J. A review of commitment and implementation of sustainable development in higher education: Results from a worldwide survey. J. Clean. Prod. 2015, 108, 1-18. [CrossRef]

19. Velazquez, L.; Munguia, N.; Sanchez, M. Deterring sustainability in higher education institutions: An appraisal of the factors which influence sustainability in higher education institutions. Int. J. Sustain. High. Educ. 2005, 6, 383-391. [CrossRef]

20. Velazquez, L.; Munguia, N.; Platt, A.; Taddei, J. Sustainable university: What can be the matter? J. Clean. Prod. 2006, 14, 810-819. [CrossRef]

21. Ferreira, J.A. Unsettling orthodoxies: Education for the environment/for sustainability. Environ. Educ. Res. 2009, 15, 607-620. [CrossRef]

22. Rickinson, M.; Lundholm, C. Exploring students' learning challenges in environmental education. Camb. J. Educ. 2008, 38, 341-353. [CrossRef]

23. Stanitsas, M.; Vareilles, É.; Kirytopoulos, K.; Aldanondo, M. Sustainable development in serious games: rethinking game-based learning strategies for master's degree engineers. In Proceedings of the MOSIM'18-12ème Conférence Internationale de Modélisation, Optimisation et SIMulation, Toulouse, France, June 2018; pp. 589-596.

24. Breßler, J.; Kappler, S. A Systematic Review of Education for Sustainable Development (No. 007); Chemnitz Economic Papers; Chemnitz University of Technology, Faculty of Economics and Business Administration: Chemnitz, Germany, 2017.

25. Scott, W. Education for sustainable development (ESD): A critical review of concept, potential and risk. In Schooling for Sustainable Development in Europe; Jucker, R., Mathar, R., Eds.; Springer: Dordrecht, The Netherlands, 2015; pp. 47-70.

26. White, H.D.; McCain, K.W. Visualizing a discipline: An author co-citation analysis of information science, 1972-1995. J. Am. Soc. Inf. Sci. 1998, 49, 327-355. 
27. Hallinger, P. Science mapping the knowledge base on educational leadership and management from the emerging regions of Asia, Africa and Latin America, 1965-2018. Educ. Manag. Adm. Leadersh. 2019. [CrossRef]

28. Hallinger, P.; Kovačević, J. A Bibliometric Review of Research on Educational Administration: Science Mapping the Literature, 1960 to 2018. Rev. Educ. Res. 2018. [CrossRef]

29. Moher, D.; Liberati, A.; Tetzlaff, J.; Altman, D.G.; PRISMA Group. Preferred reporting items for systematic reviews and meta-analyses: The PRISMA statement. Plos Med. 2009, 6, e1000097. [CrossRef]

30. Van Eck, N.J.; Waltman, L. Visualizing bibliometric networks. In Measuring Scholarly Impact: Methods and Practice; Ding, Y., Rousseau, R., Wolfram, D., Eds.; Springer: Dordrecht, The Netherlands, 2014; pp. 285-320.

31. Small, H. Visualizing science by citation mapping. J. Am. Soc. Inf. Sci. 1999, 50, 799-813. [CrossRef]

32. Johnson, D.; Beloff, B. Educating future leaders for a sustainable path. Environ. Qual. Manag. 1998, 7, 31-39. [CrossRef]

33. Wiek, A.; Withycombe, L.; Redman, C.L. Key competencies in sustainability: A reference framework for academic program development. Sustain. Sci. 2011, 6, 203-218. [CrossRef]

34. Barth, M.; Godemann, J.; Rieckmann, M.; Stoltenberg, U. Developing key competencies for sustainable development in higher education. Int. J. Sustain. High. Educ. 2007, 8, 416-430. [CrossRef]

35. Lozano, R.; Lukman, R.; Lozano, F.J.; Huisingh, D.; Lambrechts, W. Declarations for sustainability in higher education: Becoming better leaders, through addressing the university system. J. Clean. Prod. 2013, 48, 10-19. [CrossRef]

36. Leal Filho, W. Dealing with misconceptions on the concept of sustainability. Int. J. Sustain. High. Educ. 2000, 1, 9-19. [CrossRef]

37. Shephard, K. Higher education for sustainability: Seeking affective learning outcomes. Int. J. Sustain. High. Educ. 2008, 9, 87-98. [CrossRef]

38. Wals, A.E.; Jickling, B. "Sustainability" in higher education: From doublethink and newspeak to critical thinking and meaningful learning. Int. J. Sustain. High. Educ. 2002, 3, 221-232. [CrossRef]

39. Lozano, R. Diffusion of sustainable development in universities' curricula: An empirical example from Cardiff University. J. Clean. Prod. 2010, 18, 637-644. [CrossRef]

40. Brundiers, K.; Wiek, A.; Redman, C.L. Real-world learning opportunities in sustainability: From classroom into the real world. Int. J. Sustain. High. Educ. 2010, 11, 308-324. [CrossRef]

41. Steiner, G.; Posch, A. Higher education for sustainability by means of trans-disciplinary case studies: An innovative approach for solving complex, real-world problems. J. Clean. Prod. 2006, 14, 877-890. [CrossRef]

42. Thomas, I. Sustainability in tertiary curricula: What is stopping it happening? Int. J. Sustain. High. Educ. 2004, 5, 33-47. [CrossRef]

43. Ferrer-Balas, D.; Adachi, J.; Banas, S. An international comparative analysis of sustainability transformation across seven universities. Int. J. Sustain. High. Educ. 2008, 9, 295-316. [CrossRef]

44. Wright, T.S. Definitions and frameworks for environmental sustainability in higher education. High. Educ. Policy. 2002, 15, 105-120. [CrossRef]

45. Shriberg, M. Institutional assessment tools for sustainability in higher education: Strengths, weaknesses, and implications for practice and theory. High. Educ. Policy. 2002, 15, 153-167. [CrossRef]

46. Svanström, M.; Lozano-García, F.J.; Rowe, D. Learning outcomes for sustainable development in higher education. Int. J. Sustain. High. Educ. 2008, 9, 339-351. [CrossRef]

47. Warburton, K. Deep learning and education for sustainability. Int. J. Sustain. High. Educ. 2003, 4, 44-56. [CrossRef]

48. Sharp, L. Green campuses: The road from little victories to systemic transformation. Int. J. Sustain. High. Educ. 2002, 3, 128-145. [CrossRef]

49. Lozano, R. Incorporation and institutionalization of SD into universities: Breaking through barriers to change. J. Clean. Prod. 2006, 14, 787-796. [CrossRef]

50. Lozano, R.; Huisingh, D. Inter-linking issues and dimensions in sustainability reporting. J. Clean. Prod. 2011, 19, 99-107. [CrossRef]

51. Cotton, D.; Bailey, I.; Warren, M.; Bissell, S. Revolutions and second-best solutions: Education for sustainable development in higher education. Stud. High. Educ. 2009, 34, 719-733. [CrossRef] 
52. Alshuwaikhat, H.M.; Abubakar, I. An integrated approach to achieving campus sustainability: Assessment of the current campus environmental management practices. J. Clean. Prod. 2008, 16, 1777-1785. [CrossRef]

53. Sterling, S.; Thomas, I. Education for sustainability: The role of capabilities in guiding university curricula. Int. J. Innov. Sustain. Dev. 2006, 1, 349-370. [CrossRef]

54. Van Weenen, H. Towards a vision of a sustainable university. Int. J. Sustain. High. Educ. 2000, 1, $20-34$. [CrossRef]

55. Cochran, W.G. Sampling Techniques-3; John Wiley and Sons: New York, NY, USA, 1977.

56. Yamane, T. Statistics: An Introductory Analysis; Harper Row: New York, NY, USA, 1973.

57. Lozano, R. The state of sustainability reporting in universities. Int. J. Sustain. High. Educ. 2011, 12, 67-78. [CrossRef]

58. Barth, M.; Adomßent, M.; Fischer, D.; Richter, S.; Rieckmann, M. Learning to change universities from within: A service-learning perspective on promoting sustainable consumption in higher education. J. Clean. Prod. 2014, 62, 72-81. [CrossRef]

59. Hesselbarth, C.; Schaltegger, S. Educating change agents for sustainability-Learnings from the first sustainability management master of business administration. J. Clean. Prod. 2014, 62, 24-36. [CrossRef]

60. Lambrechts, W.; Mulà, I.; Ceulemans, K.; Molderez, I.; Gaeremynck, V. The integration of competences for sustainable development in higher education: An analysis of bachelor programs in management. J. Clean. Prod. 2013, 48, 65-73. [CrossRef]

61. Shephard, K. Higher education's role in 'education for sustainability'. Aust. Univ. Rev. 2010, 52, 13-19.

62. Wals, A.E. Sustainability in higher education in the context of the UN DESD: A review of learning and institutionalization processes. J. Clean. Prod. 2014, 62, 8-15. [CrossRef]

63. Corcoran, P.B.; Wals, A.E. Higher Education and the Challenge of Sustainability; Kluwer: Dordrecht, The Netherlands, 2004.

64. Sterling, S. Higher education, sustainability, and the role of systemic learning. In Higher Education and the Challenge of Sustainability; Corcoran, P., Wals, A., Eds.; Springer: Dordrecht, The Netherlands, 2004; pp. 49-70.

65. Price, D. Networks of scientific papers. Science 1965, 149, 510-515. [CrossRef]

66. Raffe, D.; Semple, S. Policy Borrowing or Policy Learning?: How (not) to Improve Education Systems; Centre for Educational Sociology: Edinburgh, UK, 2011.

67. Hallinger, P. Making education reform happen: Is there an 'Asian' way? Sch. Leadersh. Manag. 2010, 30, 401-418. [CrossRef]

68. Sachs, J.D. The Age of Sustainable Development; Columbia University Press: New York, NY, USA, 2015.

69. List, D. Action research cycles for multiple futures perspectives. Futures 2006, 38, 673-684. [CrossRef]

70. Kerkhoff, S.N. Designing global futures: A mixed methods study to develop and validate the teaching for global readiness scale. Teach. Teach. Educ. 2017, 65, 91-106. [CrossRef]

71. Mitleton-Kelly, E. Complexity Research-Approaches and Methods: The LSE Complexity Group Integrated Methodology. 2003, 1. Available online: http://emk-complexity.s3.amazonaws.com/projects/ICoSS/ approachandmethods.pdf. (accessed on 6 April 2019).

72. Phelps, R.; Hase, S. Complexity and action research: Exploring the theoretical and methodological connections. Educ. Action Res. 2002, 10, 507-524. [CrossRef]

(C) 2019 by the authors. Licensee MDPI, Basel, Switzerland. This article is an open access article distributed under the terms and conditions of the Creative Commons Attribution (CC BY) license (http://creativecommons.org/licenses/by/4.0/). 